\section{Magnetic Arrangement of Clouds}

THERE is a small literature on the absve subject (dating back to the time of the publication of Humboldt's Cosmos) which seems to have escaped the attention of $\mathrm{Mr}$. Romanes. He will find a large number of observations similar to those mentioned in NATURE, vol. xxvii. p. $3 \mathrm{I}$, recorded in a paper in the Phil. Mag. for July, I 853, by Mr. W. Stevenson, of Dunse. Similar observations have been made by Mr. Birt, Met. Mag. January, I876, and by several others in this country. M. André Poëy also deals with the subject at some length in his work, "Comment on observe les Nuages," chap. iv.

The apparent arrangement of cirri-form clouds " round two opposite poles" is simply the optical effect of the parallelism of the belts of ice-cloud, or "cirrus-band:," as Humboldt designated them. These belts are coincident in direction with what were, at the time of the formation of the clouds, lines of eqnal pressure in that horizontal plane in which the clouds float; or, in other words, their direction is normal to that of the atmospheric gra. dient at the cirrus-level. Their position, and therefore that of their vanishing points, has never been proved to have any relation to the position of the magnetic poles. It is true that in Europe a direction coincident with the wagnetic meridian is slightly more common than a direction transverse thereto. But this is explained by the fact that the formation of the bands requires somew hat steep gradients in the regions of the cirrus, and that, with us, the steepest gradients in those regions are commonly the north-eastward, being those which prevail in front of and between the cyclonic disturbances at the earth's surface, which travel towards north-east. Thus, the best defined cirrus-bands most commonly stretch from north-west to south-east.

A detailed explanation of the formation of the belts, which bears some similarity to that given by Lamarck, and which is in many, but perhaps not in all points satisfactory, will be found in a paper by Max Möller in the "Annalen der Hydrographie und Maritimen Meteorologie. Organ des Hydrographischen Amtes und der Deutschen Seewarte," I882, heft iv. pp. 212-226.

The attem ts which have been frequently made to apply the terms " polarisation," "polar bands," \&c , to the cirrus belts have proved unsuccessful, and will nst, it is to be hoped, be renewed.

W. Clement Ley

November II

\section{"A Curious Hilo"}

THE phenomenon described in NATURE (vol. xxvi. pp. 268, 293, xxvii. p. 30) is far from being unknown in Europe, where it generally receives the title of "Rayons du Crépuscule", although I do not think that it ever presents the brilliant appearance described by Father Marc Dechevrens as noticeable in China. In England it is more common in the winter than in the summer months, and does not appear to occur especially in warm weather, although I do not know that it has been noticed during frost. The furrows between the bands of light are not, so far as I have observed, rapidly movable in the sky in England, and they seem to be traceable to hills beneath the horizon, rather than to cumuli. I have never noticed them where the sun sets beneath a sea horizon.

W. Clement Ley

The phenomenon described by $M$. Dechevrens as often witnessed in China, I have several times seen in this country, namely, beams or spokes in the eastern sky about sunset, springing from a point due opposite to the sun. The appearance is not very strongly marked, and I used to think I must have been mistaken, till I came to see the true explanation, which was the same as that furnished by your correspondent.

There seems no reason why the phenomenon should not be common, and perhaps if looked out for it would be found to be. But who looks east at sunset? Something in the same way everybody has seen the rainbow; but the solar halo, which is really commoner, few people, not readers of scientific works, have ever seen at all. The appearance in question is due to cloud-shadows in an unusual perspective and in a clear sky; now shadow may not only be seen carried by misty, mealy, dusty, or smoky air near the ground, but even on almost every bright day, by seemingly clear air high overhead. Therefore, if this suncet phenomenon is much commoner in China, there must one would think, be some other reason for it than that the sky of England is not heavily charged enough with vapour to carry shadow. Rather it is to much charged, and the edge of the shadow becomes lost with distance and with the thickening of the air towards the horizon before the convergence of the beams eastwards is marked enough to catch the eye.

I may remark that things common at home have sometimes first been remarked abroad. The stars in snow were first observed in the polar regions; it was thougint that they only aroe there, but now everyone sees them with the naked eye on his coatsleeve.

Stonyhurst College

\section{Priestley and Lavoisier}

I AM sorry that Mr. Rodwell should have thought it necessary to revive the old oxygen quarrel, and the more so, as he has taken an unpatriotic part against Priestley, and indor: ed the complacent statement of Wurtz, that chemistry is a French science founded by Lavoisier; forgetting, werhaps, that the title, "La Chimie Française," was invented by lourcroy, and objected to by Lavoisier.

The fact is, that chemistry has no natimality. It belongs to the universal republic of Nature, and hat no proper existence for us until Dalton discovered its laws.

In the scientific democracy, to lue Loud Bacon's expression, discoverers are mutually dependent, and it would perhaps be impossible to find any one capable of tanding alone. It has even been charged against our great $\mathrm{N} e w$ ton that his astronomical discoveries are to be found in liepler; but, as Ir. Whewell well remarks, it required a Nevton to find them there.

That the compound is always equal to the sum of its elements, was known long before Lavoisier, and so early as 1630 Rey gave the true explanation of the increase of the weight of metals by calcination. Lavoisier's note of 1772 was, as be admitted, based upon Priestley's earlier experiments, begun in I 744 ; while the acceptance of Lavoisier's doctrine was mainly due to the capital discovery of the composition of water by Cavendish, in I 784 .

If at this advanced period we are required to put in national claims, then surely our own countryme!: must share largely in the honours which Mr. Rodwell reserves for Lavoisier alone. Black, Priestley, and Cavendish are the founders of pneumatic chemistry. Priestley di covered oxyger in 1774. Cavendi h discovered hydrogen in $\mathbf{1 7} 84$, while $D$ vy abjured Lavoisier's principe oxygene, and by his numerous di coveries gave ! he chemical edifice so rude a shake, that it had to be taken do $\mathrm{n}$ and rebuilt.

Highgate; N., November 4

C. TOMLINSON

\section{Wire Guns}

IN the last number of NATURE there is an interesting paper on "Wire Guns," and incidentally various methods of manufacturing guns is mentioned. Apropos of this permit me to relate a curious fact regarding gunmaking which came under my notice many years ago, and which supports the adage that there is nothing new under the sun. In the autumn of $184 \mathrm{I} \mathrm{Sir}$ Fr. Gough took the batteries of Chusan by a turning movement and thus spoiled the Chinese preparations. The force captured a large number of gans, some very fine bronze ones, but there were also a good many smaller iron ones, and as these were of no value they were ordered to be destroyed. The Royal Artillery tried to burst these without success at first, and only after sinking the muzzles in the ground did they succeed. It was then ascertained that the reason of the extreme strength of the gun arose from its strange manufacture. It had an inner tube of wrought iron, over which the gun was cast, anticipating by many years a somewhat similar plan by Palliser.

Cheltenham, November 3

W. H. C. B.

\section{Palæolithic River Gravels}

Mr. C. Evans, in Nature, vol. xxvii. p. 8, wishes our anthropologists to furnish an explanation why the mortal remains of palæolithic man are not to be found amongst his "so-called "flint implements."

The question is one that naturally occurs to any one whose practical acquaintance with anthropolo ical "finds" is of a limited character; and it may fairly be presumed that the inquirer bas not bimelf seen and handled such relics, else he would scarcey have imagined it within the range of poscibi ity that they could have been "formed by natural causes," by which, I suppose, he wishes to infer that they were not made ty man. 